\title{
An association between maternal lead and cadmium levels and birth weight of the babies in North Indian population
}

\author{
Divya Dwivedi, Madhu Jain, Shuchi Jain \\ Department of Obstetrics \& Gynaecology, Institute of Medical Sciences, Banaras Hindu University, Varanasi, India \\ Email: drmadhujainbhu@gmail.com
}

Received 19 February 2013; revised 20 March 2013; accepted 28 March 2013

Copyright (C) 2013 Divya Dwivedi et al. This is an open access article distributed under the Creative Commons Attribution License, which permits unrestricted use, distribution, and reproduction in any medium, provided the original work is properly cited.

\begin{abstract}
Lead is listed as the 2 nd and Cadmium as the 7th hazardous substance by the Agency for Toxic Substances and Disease Registry (ATSDR). Exposure to Lead and Cadmium above the permissible levels among pregnants may cause adverse effects on newborns in the form of Low Birth Weight and Preterm Labor, etc. The objectives of this study were to find out the level of Lead and Cadmium in maternal venous blood and cord blood and to find out the association of the levels of these metals with birth weight of babies. For this, the venous blood and cord blood were collected and quantitative estimation of Lead and Cadmium was carried out by Double Beam Atomic Absorption Spectrophotometer in 1000 women with average Body Mass Index. Results showed higher mean maternal blood Lead level $(11.08 \mu \mathrm{g} / \mathrm{dl}$ with range of 2.6 - 21.3) than the normal recommended by Centre of Disease Control and Prevention (10 $\mu \mathrm{g} / \mathrm{dl})$. On the contrary, the mean Cadmium level was $0.095 \mu \mathrm{g} / \mathrm{dl}$, which was below the normal value as assigned by WHO (0.1 $\mu \mathrm{g} / \mathrm{dl})$. In high Lead exposure group (>10 $\mu \mathrm{g} / \mathrm{dl})$, 43.7\% of babies and in high Cadmium exposure group $(>0.1 \mu \mathrm{g} / \mathrm{dl}), 46.2 \%$ of babies were found to have low birth weight. However, this was not statistically significant. Further research in this area in a larger sample size may provide information relevant enough to be transferred to decision makers to implement measures to effectively reduce heavy metals from the environment, thereby protecting future generations from their deleterious effects.
\end{abstract}

Keywords: Lead; Cadmium; Environmental Exposure; Birth Weight; Venous Blood; Cord Blood

\section{INTRODUCTION}

Both developed as well as developing countries are con- cerned with dispersion of toxic heavy metals in the environment. Among these, Lead $(\mathrm{Pb})$ and Cadmium $(\mathrm{Cd})$ have increasingly become the important environmental pollutants. Lead is listed as 2nd and Cadmium as 7th hazardous substance by the Agency for Toxic Substances and Disease Registry (ATSDR) and Environmental Protection Agency (EPA) of the United States in 2001 [1]. Adverse effects of these metals may be in form of acute poisoning or due to chronic exposure. Chronic exposure may result in damaged or reduced mental and central nervous system functions, lower energy levels, damage to blood components, lungs, kidneys, liver and other vital organs [2]. Children and pregnant women are the most adversely affected segments of population. Exposure to $\mathrm{Pb}$ may cause preterm labor, intrauterine growth retardation [3], low birth weight babies [4], abortions, intrauterine deaths, still births $[5,6]$ and poor neurocognitive behavior of the babies in future [6-8]. Although there are very limited data on the development effects of $\mathrm{Cd}$ in humans, a number of studies indicated that $\mathrm{Cd}$ could be fetotoxic during gestation, leading to low birth weight (LBW) $[9,10]$, and increased incidence of spontaneous abortions [11].

Birth weight is a strong predictor of survival and of development outcomes in childhood including growth, morbidity and cognitive performance. High-level occupational $\mathrm{Pb}$ exposures have been associated with adverse pregnancy outcomes, but studies of lower level $\mathrm{Pb}$ exposure on birth weight in community settings have yielded inconsistent findings [12-14]. Also several previous studies $[10,15,16]$ focused on the possible toxic effects of environmental $\mathrm{Cd}$ exposure on birth weight, preterm labor, malformations and neurobehavioral development, but there was no consistent conclusion. As the area zone of our study is not heavily exposed to $\mathrm{Pb}$ and $\mathrm{Cd}$, it may yield some results regarding effects of low dose exposure. Hence, the objectives of our study were to find out levels of $\mathrm{Pb}$ and $\mathrm{Cd}$ exposure in the study population, extent of transfer of these metals across 
placental barrier and to find out if there was any association between $\mathrm{Pb}$ and $\mathrm{Cd}$ levels in the maternal venous blood with birth weight of the babies.

\section{MATERIALS AND METHODS}

The study population consisted of 1000 antenatal females (booked/unbooked) of average BMI, visiting Department of Obstetrics and Gynecology, Sir Sunderlal Hospital, Banaras Hindu University, Varanasi, India. They belonged to eastern part of Uttar Pradesh and western part of Bihar states of India. This population is generally of low to average socio-economic status and is more prone to exposure to $\mathrm{Pb}$ and $\mathrm{Cd}$ through use of coal for household and breathing cigarette's smoke, bidi smoke and automobile exhaust and contaminated drinking water from the well and hand pumps.

Exclusion criterion included factors that interface with maternal calcium metabolism like patient taking calcium channel blockers, hyper or hypo-parathyroid states, osteoporosis, etc., medical conditions that can cause LBW babies, viz. anaemia, hypertension, chronic renal disease, etc. and obstetrical conditions that can cause LBW babies, viz., multiple pregnancies, polyhydramnios, pregnancy induced hypertension, antepartum, hemorrhage, pre-mature rupture of membranes, etc.

An informed consent was taken from participants. Baseline information was collected on their health status, social and demographic characteristics. More informaion was sought about potential $\mathrm{Pb}$ exposures viz. use of $\mathrm{Pb}$ paints, surma (black soot), source of drinking water, mode of cooking (Liquefied Petroleum Gas or earthenware cooking device using coal i.e. "chulha"), tobacco smoking and chewing habit of mother, residence in congested inner city and exposure to automobile exhausts. Data were also collected on potential confounders like maternal age, weight and height, gestational age, parity of mothers, details about previous pregnancies, nutriational status, intake of iron and calcium during antenatal period, hemoglobin, socio-economic status of parents, education level of wife and husband.

The new born birth weight was recorded without clothing on a UNICEF beam balance immediately after birth. For the purpose of analysis, low birth weight (LBW) babies are considered with weight less than 2.5 $\mathrm{kg}(2500 \mathrm{gm})$. The mothers with hemoglobin $<10 \mathrm{~g} \%$ were considered as anemic.

For measurement of level of $\mathrm{Pb}$ and $\mathrm{Cd}$, about $6 \mathrm{ml}$ of venous blood of mother and cord blood were collected separately from the pregnant women. Venous blood was collected at the time of delivery from the antecubital vein. Cord blood was collected from the placental end without milking the cord just after the third stage of labor. Soon after the collection, the vials were labeled and refrigerated and transported to the laboratory for further analysis.
Samples were frozen at $-40^{\circ} \mathrm{C}$ in the laboratory until quantitative estimation of $\mathrm{Pb}$ and $\mathrm{Cd}$ with Double Beam Atomic Absorption Spectrophotometer (AAS, SL194, Elico, Hyderabad) was carried out.

For analysis, maternal venous $\mathrm{Pb}(\mathrm{PbVB})$ and cord blood $\mathrm{Pb}(\mathrm{PbCB})$ were categorized into two groups, using $\mathrm{Pb}$ level of $10 \mu \mathrm{g} / \mathrm{dl}$ as cut off [17], group one being $\mathrm{PbVB}$ less than or equal to $10 \mu \mathrm{g} / \mathrm{dl}$ and group two having PbVB more than $10 \mu \mathrm{g} / \mathrm{dl}$. Similarly for $\mathrm{Cd}$, group one is with Cd level less than or equal to $0.1 \mu \mathrm{g} / \mathrm{dl}$ and group two with $\mathrm{Cd}$ level more than $0.1 \mu \mathrm{g} / \mathrm{dl}$ for both $\mathrm{CdVB}$ and $\mathrm{CdCB}$ as the acceptable value of blood $\mathrm{Cd}$ level given by WHO (2007) is $0.1 \mu \mathrm{g} / \mathrm{dl}$ [18]. Univariate distribution of potential confounders and main outcome variable (birth weight) and secondary outcomes were studied. The statistical analysis of data was done with SPSS 16 version using student " $\mathrm{t}$ " test, chi-square test and multivariate logistic linear and stepwise regression analysis.

\section{RESULTS AND DISCUSSION}

\subsection{Population Characteristics}

The average pre-pregnancy Body Mass Index (BMI) of these subjects was $21.78 \mathrm{~kg} / \mathrm{m}^{2}$. Among these pregnant women, $54 \%$ belonged to age group 25 - $30 \mathrm{yrs}, 49.5 \%$ were 2 nd or 3 rd gravida, and $30 \%$ received education upto Xth standard, $68.5 \%$ consumed iron and calcium in their antenatal period for minimal prescribed period and only $16.5 \%$ women were anemic at the time of delivery. None of the pregnant women had a habit of smoking or drinking alcohol. The mean birth weight of babies of the participating mothers was $2683.49 \mathrm{gm}$ i.e. above the criteria for low birth weight babies (Table 1).

\subsection{Environmental Lead and Cadmium Exposure}

Maternal blood $\mathrm{Pb}$ levels (PbVB) of the pregnant women ranged from 2.6 to $21.3 \mu \mathrm{g} / \mathrm{dl}$ having mean as 11.08 $\mu \mathrm{g} / \mathrm{dl}$ (Table 2), which is more than the recommended level of $\mathrm{Pb}$ by Center for Disease Control and Prevention i.e. $10 \mu \mathrm{g} / \mathrm{dl}$ [17]. Recent research [18] and pooled analysis of seven prospective studies [8] emphasized on prompt consideration of further reduction of such $\mathrm{Pb}$ level. In our study, surprisingly, 625 out of 1000 (62.5\%) subjects had PbVB above the limit recommended by Centre for Disease Control $(10 \mu \mathrm{g} / \mathrm{dl})$. The mean Pb level recorded during our study was comparable to The Port Pirie Study $(11.2 \mu \mathrm{g} / \mathrm{dl})$ [19], but much higher than the study in Norway $(1.25 \mu \mathrm{g} / \mathrm{dl})$, Russia $(2.92 \mu \mathrm{g} / \mathrm{dl})$ [20] and Mexico City $(7.26 \mu \mathrm{g} / \mathrm{dl})$ [21]. The mean maternal venous blood $\mathrm{Cd}$ level (CdVB) in our study was 0.095 $\mu \mathrm{g} / \mathrm{dl}$, with the range being $0.059 \mu \mathrm{g} / \mathrm{dl}$ to $0.86 \mu \mathrm{g} / \mathrm{dl}$ 
Table 1. Distribution of birth weight (Mean $\pm \mathrm{SD}$ ) according to various maternal variables.

\begin{tabular}{|c|c|c|c|c|}
\hline S.No. & Variables & No. $(\%)$ & Birth weight (in g) (Mean \pm SD) & P-value \\
\hline 1 & $\begin{array}{c}\text { Maternal age groups (in yrs) } \\
<25 \\
25-30 \\
>30\end{array}$ & $\begin{array}{c}365 \\
540 \\
95\end{array}$ & $\begin{array}{l}2620.75 \pm 402.46 \\
2729.49 \pm 405.69 \\
2661.94 \pm 478.16\end{array}$ & 0.000 \\
\hline 2 & $\begin{array}{l}\text { Gestational age (in weeks) } \\
37-38 \\
39-40 \\
\geq 41\end{array}$ & $\begin{array}{c}720 \\
235 \\
45\end{array}$ & $\begin{array}{c}2626.4 \pm 425.91 \\
2781.01 \pm 333.04 \\
2988.89 \pm 456.41\end{array}$ & 0.000 \\
\hline 3 & $\begin{array}{l}\text { Parity } \\
\text { Primi } \\
2-3 \\
\geq 4\end{array}$ & $\begin{array}{l}400 \\
495 \\
105\end{array}$ & $\begin{array}{l}2654.80 \pm 379.15 \\
2712.11 \pm 422.53 \\
2614.40 \pm 518.02\end{array}$ & 0.031 \\
\hline 4 & $\begin{array}{c}\text { Maternal education } \\
\text { Illiterate } \\
\text { Upto High school } \\
\text { Upto Intermediate } \\
\text { Graduation and above }\end{array}$ & $\begin{array}{l}320 \\
300 \\
200 \\
180\end{array}$ & $\begin{array}{l}2414.7 \pm 390.93 \\
2663.3 \pm 478.61 \\
2607.3 \pm 336.06 \\
2812.7 \pm 360.96\end{array}$ & 0.000 \\
\hline 5 & $\begin{array}{c}\text { Father's Income (per month, in Rs.) } \\
\qquad \begin{array}{c}<10,000 \\
10,000-20,000 \\
>20,000\end{array}\end{array}$ & $\begin{array}{l}325 \\
490 \\
185\end{array}$ & $\begin{array}{l}2573.33 \pm 455.66 \\
2606.42 \pm 338.32 \\
2906.80 \pm 416.10\end{array}$ & 0.000 \\
\hline 6 & $\begin{array}{l}\text { Duration of iron and calcium consumption in antenatal period } \\
\qquad \begin{array}{c}\text { (in days) }<100 \\
>100\end{array}\end{array}$ & $\begin{array}{l}315 \\
685\end{array}$ & $\begin{array}{l}2530.65 \pm 398.60 \\
2752.66 \pm 401.17\end{array}$ & 0.000 \\
\hline 7 & $\begin{array}{l}\text { Maternal hemoglobin at time of delivery } \\
\qquad<10 \mathrm{~g} \% \\
>10 \mathrm{~g} \%\end{array}$ & $\begin{array}{l}165 \\
835\end{array}$ & $\begin{array}{l}2303.33 \pm 350.73 \\
2753.32 \pm 387.64\end{array}$ & 0.000 \\
\hline
\end{tabular}

Table 2. Lead and Cadmium concentration in maternal venous blood and cord blood.

\begin{tabular}{cccc}
\hline Concentration $(\mu \mathrm{g} / \mathrm{dl})$ & No. & Mean $(\mu \mathrm{g} / \mathrm{dl})$ & $\mathrm{SD}$ \\
\hline Lead in venous blood $(\mathrm{PbVB})$ & 960 & 11.08 & 3.47 \\
Lead in cord blood $(\mathrm{PbCB})$ & 875 & 7.37 & 3.05 \\
Cadmium in venous blood $(\mathrm{CdVB})$ & 780 & 0.095 & 0.077 \\
Cadmium in cord blood $(\mathrm{CdCB})$ & 410 & 0.051 & 0.017 \\
\hline
\end{tabular}

(Table 2). The acceptable value of blood Cd level $(0.1$ $\mu \mathrm{g} / \mathrm{dl})$ given by WHO (2007) [22] is higher than those recorded during the present study. The mean Cd level in our study was also less than the study done in Daye City of Hubei province $(0.231 \mu \mathrm{g} / \mathrm{dl})$ [23], in Norway $(1.2$ $\mu \mathrm{g} / \mathrm{dl})$ and in Russia $(2.4 \mu \mathrm{g} / \mathrm{dl})$ [20]. In our study, only 130 out of 1000 i.e. $13 \%$ subjects had Cd level above 0.1 $\mu \mathrm{g} / \mathrm{dl}$. These figures suggest that there is low environmental exposure to $\mathrm{Cd}$ in our study population.

\subsection{Amount of Lead and Cadmium Crossing the Placental Barrier}

Pearson's correlation showed that concentration of $\mathrm{Pb}[\mathrm{r}$
$=0.922 ; \mathrm{p} \leq 0.001]$ and $\mathrm{Cd}[\mathrm{r}=0.713 ; \mathrm{p} \leq 0.001]$ in maternal venous blood was significantly higher than that in cord blood and they were positively correlated to each other. Similar to the study in Pittsburgh [24] $(\mathrm{r}=0.79)$ and Mexico [21] [r =0.544; $\mathrm{p}<0.001]$, we have also found that placenta protects the foetus in some way from environmental exposure. Lead is known to cross the placental barrier by diffusion, but how much percentage of $\mathrm{Pb}$ reaches placenta is not clear. This percentage, in our study, was 66.5, which was lower than that reported in studies in Pittsburgh (84.9) [24] and Mexico (85.4) [21], but the percentage of $\mathrm{Cd}$ crossing the placenta in our study was much higher (60\%) than that in study in Daye city of Hubei province (17.14\%) [23]. Unlike $\mathrm{Pb}$, the mechanism of $\mathrm{Cd}$ transfer across placenta is unknown.

\subsection{Effects of Lead on Neonatal Birth Weight}

There is conclusive evidence in both human and animals that $\mathrm{Pb}$ crosses the placenta and accumulates in fetal tissues at least after $12 \mathrm{wks}$ of pregnancy in human $[25,26]$. The level of PbVB showed a U shaped pattern (Figure 1) i.e. a decline in lead between weeks 12 and 20 followed by a rise that continued throughout the remainder of 
pregnancy [27]. PbVB increases with age, smoking, loweducational level, African-American race and decreases with history of breastfeeding and higher intake of calum [27].

Lead is an important environmental pollutant which may cause several adverse fetal outcomes including low birth weight. Although, the mechanism by which $\mathrm{Pb}$ may reduce birth weight is not fully known, it is supposed to have both local and systemic effects. By local effect, it decreases fetal skeletal growth after getting deposited in fetal osteocytes and systemically, it has an affinity for fetal thyroid tissue causing decrease in thyroxin levels which in turn causes decrease in soft tissue organ growth leading to decrease in birth weight [3].

In the present study, among low $\mathrm{Pb}$ exposure group $(\leq 10 \mu \mathrm{g} / \mathrm{dl}), 23.9 \%$ babies were of low birth weight (LBW), whereas in high $\mathrm{Pb}$ exposure group $(>10 \mu \mathrm{g} / \mathrm{dl})$, $44 \%$ babies were LBW $[p=0.000]$. Similar variations of birth weight were found with $\mathrm{PbCB}$ also $[\mathrm{p}<0.000]$ (Table 3). But after adjustment for maternal age, parity, gestational age, hemoglobin at the time of delivery and BMI, no significant association was found between maternal $\mathrm{Pb}$ level and birth weight of the baby.

There are conflicting reports on effects of fetal $\mathrm{Pb}$ exposure on birth weight. Increase in birth weight $[28,29]$,

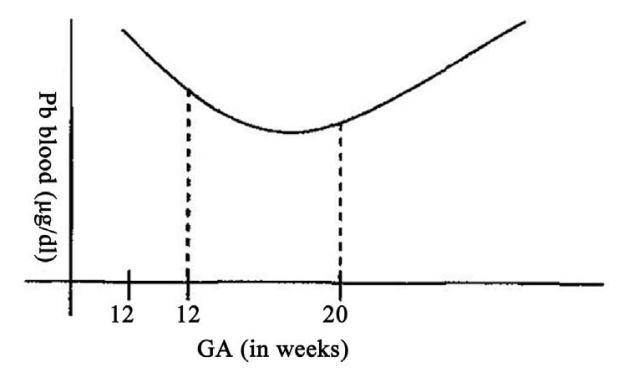

Figure 1. U shaped pattern of $\mathrm{PbVB}$ during pregnancy.

Table 3. Distribution of babies according to their birth weight and maternal venous $\mathrm{Pb}$ and $\mathrm{Cd}$ levels.

\begin{tabular}{|c|c|c|c|c|c|}
\hline \multirow{2}{*}{ Variables } & \multirow{2}{*}{ Groups } & \multicolumn{2}{|c|}{ Weight of baby (gm) } & \multirow{2}{*}{$\chi^{2}$} & \multirow{2}{*}{$\mathrm{p}$-value } \\
\hline & & $<2500$ gm $(\%$ & $2500 \mathrm{gm}(\%)$ & & \\
\hline \multirow{2}{*}{$\mathrm{PbVB}$} & $\leq 10 \mu \mathrm{g} / \mathrm{dl}$ & $80(23.9)$ & $255(76.1)$ & \multirow{2}{*}{37.88} & \multirow{2}{*}{0.000} \\
\hline & $>10 \mu \mathrm{g} / \mathrm{dl}$ & $275(44.0)$ & $350(56.0)$ & & \\
\hline \multirow{2}{*}{$\mathrm{PbCB}$} & $\leq 10 \mu \mathrm{g} / \mathrm{dl}$ & $235(33.6)$ & $460(66.4)$ & \multirow{2}{*}{53.88} & \multirow{2}{*}{0.000} \\
\hline & $>10 \mu \mathrm{g} / \mathrm{dl}$ & $115(61.9)$ & $65(38.1)$ & & \\
\hline \multirow{2}{*}{ CdVB } & $\leq 0.1 \mu \mathrm{g} / \mathrm{dl}$ & $250(33.5)$ & $400(61.5)$ & \multirow{2}{*}{2.68} & \multirow{2}{*}{0.102} \\
\hline & $>0.1 \mu \mathrm{g} / \mathrm{dl}$ & $60(46.2)$ & $70(53.8)$ & & \\
\hline \multirow{2}{*}{$\mathrm{CdVB}$} & $\leq 0.1 \mu \mathrm{g} / \mathrm{dl}$ & $180(45.0)$ & $230(55.0)$ & \multirow{2}{*}{0.00} & \multirow{2}{*}{1.00} \\
\hline & $>0.1 \mu \mathrm{g} / \mathrm{dl}$ & $5(50.0)$ & $5(50.0)$ & & \\
\hline
\end{tabular}

no effects $[19,30,31]$ and decrease $[3,20,32,33]$ in birth weight are reported as a result of $\mathrm{Pb}$-exposure.

Negligible effects of PbVB on birth weight on applying multiple linear regression, observed during the present study, may be explained as under :

Firstly, the observed level of PbVB $(11.08 \mu \mathrm{g} / \mathrm{dl})$ was though higher than that recommended by CDC (10 $\mu \mathrm{g} / \mathrm{dl}$ ), perhaps not high enough to affect the birth weight of the babies. Clark et al. [30] also concluded that infants can tolerate blood $\mathrm{Pb}$ levels of $37 \mu \mathrm{g} / \mathrm{dl}$ in utero without adverse effects on their birth weight.

Secondly, the variability of results from previous studies on the relationship between maternal blood $\mathrm{Pb}$ concentration and human fetal development could be due in part to the inadequacy of blood $\mathrm{Pb}$ concentration (BLL or $\mathrm{PbVB}$ ) as a marker for $\mathrm{Pb}$ toxicity. Bone $\mathrm{Pb}$ concentration [32] and plasma $\mathrm{Pb}$ concentration [34] are better markers for $\mathrm{Pb}$ toxicity than whole blood $\mathrm{Pb}$ concentration. This suggests that the indicator of fetal $\mathrm{Pb}$ exposure must involve $\mathrm{Pb}$ that is available to cross the placenta. But since $99 \%$ of $\mathrm{Pb}$ in blood is bound to $\mathrm{RBC}$, so $\mathrm{Pb}$ which is free to cross the placental barrier is the $\mathrm{Pb}$ in the plasma. Thus plasma $\mathrm{Pb}$ is a better biomarker of fetal toxicity than whole blood $\mathrm{Pb}$.

\subsection{Effects of Cadmium on Neonatal Birth Weight}

According to Environmental Health Criteria of the World Health Organization (1992) [22], evidences in humans of suppression of birth weight by $\mathrm{Cd}$ is difficult to separate from the impact of smoking. Its main toxic effect in adults is on the kidney, producing tubular dysfunction characterized by enhanced excretion of renal tubular tissue enzymes, low molecular mass proteins and other essential metabolites such as calcium and phosphate. Mild tubular dysfunction has even been associated with heavy smoking [35]. But fortunately in the present study none of the 1000 subjects was smoker.

Among low Cd exposure group $(\leq 0.1 \mu \mathrm{g} / \mathrm{dl}), 33.6 \%$ of babies were of low birth weight (LBW) whereas in high $\mathrm{Cd}$ exposure group ( $>0.1 \mu \mathrm{g} / \mathrm{dl}), 46.2 \%$ of babies were LBW (Table 3). Negative correlation of Cd in maternal venous blood with birth weight of the babies $(r=-0.067$, $p=0.402$ ) was recorded (Table 4). However, none of the above observations was statistically significant. In other words, CdVB didn't affect birth weight of the babies in our study. Nishijo et al. [16] found no significant association between maternal urinary $\mathrm{Cd}$ and birth weight, after adjustment for gestational age, suggesting that $\mathrm{Cd}$ exposure did not greatly affect fetal development, but it did affect pregnancy outcome viz. decrease in birth height, preterm deliveries, etc. Odland et al. [20] and Zhang et al. [23] also didn't find any association between $\mathrm{Cd}$ blood level and birth weight of the babies. On 
the contrary, Salpietro [36] suggested that birth weight might be negatively influenced by $\mathrm{Cd}$ levels due to the toxic effects of the metal on the placenta.

The reasons why we didn't find a significant association between $\mathrm{Cd}$ exposure level and birth weight, might be due to relatively small sample size $(\mathrm{n}=1000)$, and below detectable limits of $\mathrm{Cd}$ in nearly $1 / 5$ of the subjects. Moreover, the $\mathrm{Cd}$ pollution of the present study area was perhaps not heavy enough to cause low birth weight in infants.

Finally, on applying multiple linear regression analysis, it was found that $19.6 \%$ variation of birth weight was explained by hemoglobin and this could be further increased to $22 \%$ by adding the gestational age. By adding other predictor variables ( $\mathrm{PbVB}, \mathrm{PbCB}$ and $\mathrm{BMI})$, the total variation explained was up to $23.4 \%$. This shows that the $\mathrm{Pb}$ levels ( $\mathrm{PbVB} \& \mathrm{PbCB}$ ) and $\mathrm{BMI}$ are not the significant predictors of birth weight in the presence of hemoglobin and gestational age (Tables 4 and 5).

\section{CONCLUSIONS}

No significant association was found between level of $\mathrm{Pb}$ and $\mathrm{Cd}$ in maternal venous blood and birth weight of the babies. This could be because of lower exposure level of $\mathrm{Pb}$ and $\mathrm{Cd}$ and inadequacy of blood $\mathrm{Pb}$ level as a marker of $\mathrm{Pb}$ toxicity.

Future research should be directed at confirming these findings and to develop strategies to prevent the increase of $\mathrm{Pb}$ and $\mathrm{Cd}$ levels in pregnant women. Government and society have been remarkably slow to recognize the

Table 4. Univariate linear regression analysis.

\begin{tabular}{ccccc}
\hline $\begin{array}{c}\text { Independent } \\
\text { variable }\end{array}$ & $\begin{array}{c}\text { Correlation } \\
\text { coefficient (r) }\end{array}$ & Constant (a) & $\begin{array}{c}\text { Regression } \\
\text { coefficient (b) }\end{array}$ & p-value \\
\hline $\mathrm{PbVB}$ & -0.277 & -17.209 & -0.002 & 0.001 \\
$\mathrm{PbCB}$ & -0.207 & 2862.412 & -28.837 & 0.006 \\
$\mathrm{CdVB}$ & -0.067 & 2688.934 & -370.161 & 0.402 \\
$\mathrm{CdCB}$ & -0.115 & 2760.900 & -2699.06 & 0.304 \\
\hline
\end{tabular}

Table 5. Forward stepwise partial of independent variables regression analysis on birth weight of babies.

\begin{tabular}{|c|c|c|c|c|}
\hline Steps & $\begin{array}{l}\text { Independent } \\
\text { variables }\end{array}$ & Regression coefficient & Constant & $\begin{array}{c}\text { Percentage } \\
\text { variation } \\
\text { explained }\end{array}$ \\
\hline 1 & $\begin{array}{l}\text { Hemoglobin } \\
(\mathrm{Hb})\end{array}$ & 111.22 & 1487.85 & 19.6 \\
\hline 2 & $\begin{array}{c}\mathrm{Hb}+ \\
\text { Gestational age } \\
(\mathrm{GA})\end{array}$ & $104.35 \mathrm{Hb}+59.59 \mathrm{GA}$ & -711.55 & 22.0 \\
\hline 3 & $\begin{array}{c}\mathrm{Hb}+\mathrm{GA}+ \\
\mathrm{PbVB}+\mathrm{PbCB} \\
+\mathrm{BMI}\end{array}$ & $\begin{array}{c}99.71 \mathrm{Hb}+57.48 \mathrm{GA}- \\
4.75 \mathrm{PbVB}-12.57 \\
\mathrm{PbCB}+3.37 \mathrm{BMI}\end{array}$ & -508.63 & 23.4 \\
\hline
\end{tabular}

heavy metal exposure and to respond with appropriate abatement programmes. Further research in this are on a larger scale would provide information needed to be transferred to decision makers to implement measures to effectively eliminate heavy metals from the environment, thereby protecting future generations from their deleterious effects.

\section{REFERENCES}

[1] Agency for Toxic Substances and Disease Registry (ATSDR) (2001) Mission Statement, Top 20, Hazardous Substances.

[2] Health Concerns, Heavy Metal Toxicity. http://www.lef.org

[3] Hernandez-Avila, M., Peterson, K.E., Gonzalez-Cossio, T., et al. (2002) Effect of maternal bone lead on length and head circumference of new born and 1-month old infants. Archieves of Environmental Health, 57, 482-488. doi:10.1080/00039890209601441

[4] Osman, K., Akesson, A., Berglund, M., Bremme, K., Schutz, A., Ask, K. and Vahter, M. (2000) Toxic and essential elements in placentas of Swedish women. Clinical Biochemistry, 33, 131-138. doi:10.1016/S0009-9120(00)00052-7

[5] US Environmental Protection Agency (1979) Lead: Ambient water quality criteria and standards division, Office of water quality planning and standard. Research Triangle Park, N.C., US Environmental Protection Agency, Washington DC.

[6] Bellinger, D.C. (2005) Teratogen update: Lead and pregnancy. Birth Defects Research: Part A, Clinical and Molecular Teratology, 73, 409-420.

[7] Needleman, H.L. (2004) Low level lead exposure and the development of children. Southeast Asian Journal of Tropical Medicine and Public Health, 35, 252-254.

[8] Lanphear, B.P., Hormung, R., Khoury, J., Yolton, K., Baghurst, P., Bellinger, D., et al. (2005) Low level environmental lead exposure and children's intellectual functions: An international pooled analysis. Environmental Health Perspect, 113, 894-899. doi: $10.1289 /$ ehp.7688

[9] Shen, L.J., Fan, Q.Y., Ding, X.C. and Jin, T.Y. (2001) Influence of cadmium exposure during gestation and lactation on the growth and development of the second generation in rats. Journal of Toxicology and Environmental Health, 15, 197-200.

[10] Frery, N., Nessmann, C., Girard, F., Lafond, J., Moreau, T., Blot, P., Lellouch, J. and Huel, G. (1993) Environmental exposure to cadmium and human birth-weight. Toxicology, 79, 109-118. doi:10.1016/0300-483X(93)90124-B

[11] Shiverick, K.T. and Salafia, C. (1999) Cigarette smoking and pregnancy I: Ovarian, uterine and placental effects. Placenta, 20, 265-272. doi:10.1053/plac.1998.0377

[12] Mushak, P. (1989) Biological monitoring of lead exposure in children: Overview of selective biokinetics and 
toxicology issues. In: Smith, M.A., Grant, L.D. and Sors, A.Z., Eds., Lead Exposures in Child Development, Kluwer Academic Publishers, Boston, 129-145. doi:10.1007/978-94-009-0847-5 4

[13] Wong, G.P., Ng, T.L., Martin, T.R. and Farquiharson, D.F. (1992) Effects of low level lead exposure in utero. Obstetrical \& Gynecological Survey, 47, 285-289. doi:10.1097/00006254-199205000-00001

[14] Andrews, K.W., Savitz, D.A. and Hertz-Piecciotto, L. (1994) Prenatal lead exposure in relation to gestational age and birth weight: A review of epidemiological studies. American Journal of Industrial Medicine, 26, 13-32. doi:10.1002/ajim.4700260103

[15] Loiacono, N.J., Graziano, J.H., Kline, J.K., Popovac, D., Ahmedi, X., et al. (1992) Placental cadmium and birth weight in women living near a lead smelter. Archives of Environmental Health, 47, 250-255.

[16] Nishijo, M., Nakagawa, H., Honda, R., Tanebe, K., Saito, S., Teranishi, H. and Tawara, K. (2002) Effects of maternal exposure to cadmium on pregnancy outcome and breast milk. Occupational \& Environmental Medicine, 59, 394-397. doi:10.1136/oem.59.6.394

[17] Centers for Disease Control (CDC) (1991) Preventing lead poisoning in young children: A statement by the Centers for Disease Control. Centers for Disease Control, Atlanta.

[18] Canfield, R.L., Handerson, C.R., Lanphear, B.P., et al. (2003) Intellectual impairment in children with blood lead concentration below $10 \mu \mathrm{g} / \mathrm{dl}$. New England Journal of Medicine, 348, 1517-1526.

[19] McMichael, A.J., Vimpani, G.V., Robertson, E.F., Baghurst, P.A. and Clark, P. (1986) The port pirie cohort study: Maternal blood lead and pregnancy outcome. Journal of Epidemiology \& Community Health, 40, 18-25.

[20] Odlando, J.O., Nieboer, E., Romanova, N., Thomassen, Y. and Lund, E. (1999) Blood Lead and Cadmium and birth weight among sub-arctic populations of Norway and Russia. Acta Obstetricia et Gynecologica Scandinavica, 78, 852-860. doi:10.1080/j.1600-0412.1999.781004.x

[21] Hu, H., Tellez-Rojo, M. M., Bellinger, D., et al. (2006) Fetal lead exposure at each stage of pregnancy as a predictor of infant mental development. Environmental Health Perspectives, 114, 1730-1735.

[22] World Health Organization (WHO) (1992) Environmental health criteria, Vol. 134: Cadmium. World Health Organization, Geneva.

[23] Zhang, Y.-L., Zhao, Y.-C., Wang, J.X. et al. (2004) Effect of environmental exposure to cadmium on pregnancy outcome and fetal growth: A study on healthy pregnant women in China. Journal of Environmental Science and Health, 39, 2507-2515. doi:10.1081/ESE-200026331

[24] Harville, E.W., Hertz-Picciotto, I., Schramm, M., WattMorse, M., Chantala, K., Osterlah, J., Parsons, P.J. and Rogan, W. (2005) Factors influencing the difference between maternal and cord blood lead. Occupational \& En- vironmental Medicine, 62, 263-269. doi:10.1136/oem.2003.012492

[25] Centers for Disease Control (CDC) (1978) Criteria for a recommended standard: Occupational exposure to inorganic lead: Revised criteria. National Institute of Occupational Safety and Health (NIOSH), Washington DC.

[26] Jaworski, J.F. (1979) The effects of lead in Canadian environment. Associate committee on scientific criteria for environmental quality. Environmental secretariat. National Research Council, Ottawa.

[27] Rothenberg, S., Karcheme, S., Schnaas, L., et al. (1994) Changes in serial blood lead levels during pregnancy. Environmental Health Perspectives, 102, 876-880. doi:10.1289/ehp.94102876

[28] Wang, J.D., Shy, W.Y., Chen, J.S., et al. (1989) Parental occupational lead exposure and lead concentration of cord blood. American Journal of Industrial Medicine, 15, 111-115. doi:10.1002/ajim.4700150112

[29] Awasthi, S., Awasthi, R. and Srivastava, R.C. (2002) Maternal blood lead level and outcomes of Pregnancy in Lucknow. Indian Pediatrics, 39, 855-860.

[30] Clark, A.R.L. (1977) Placental transfer of lead and its effects on the newborn. Postgraduate Medical Journal, 53, 674-678. doi:10.1136/pgmj.53.625.674

[31] Factor-Litvak, P., Graziano, J.H., Kline, J.K., et al. (1991) A prospective study of birth weight and length of gestation in a population surrounding in lead smelter in Kosovo, Yugoslavia. International Journal of Epidemiology, 20, 722-728. doi:10.1093/ije/20.3.722

[32] González-Cossío, T., Hernández -Avilla, M., et al. (1997) Decrease in birth weight in relation to material bone-lead burden. Paediatrics, 100, 856-862. doi:10.1542/peds.100.5.856

[33] Han, S., Pfizenmaier, D.H., et al. (2000) Effects of lead exposure before pregnancy and dietary calcium during pregnancy on fetal development and lead accumulation. Environmental Health Perspectives, 108, 527-531.

[34] Chuang, H.-Y., Schwartz, J., Gonzales-Cossio, T., Lugo, M.C.; Palazuelos, E, Aro, A., Hu, H. and HemandezAvila, M. (2001) Interrelations of lead levels in bone, venous blood and umbilical cord blood with exogenous lead exposure through maternal plasma lead in peripartum women. Environmental Health Perspectives, 109, 527-532.

[35] Jarup, L., Berglund, M., Elinder, C.G., Nordberg, G. and Vahter, M. (1998) Health effects of cadmium exposureA review of the literature and a risk estimate. Scandinavian Journal of Work, Environment \& Health, 24, 1-51.

[36] Salpietro, C.D., Gangemi, S., Minciullo, P.L., Briuglia, S., Merlino, M.V., Stelitano, A., Cristani, M., Tronbetta, D. and Saija, A. (2002) Cadmium concentration in maternal and cord blood and infant birth weight: A study on healthy non-smoking women. Journal of Perinatal Medicine, 30, 395-399. doi:10.1515/JPM.2002.061 